\title{
Leptin Acts via Lateral Hypothalamic Area Neurotensin Neurons to Inhibit Orexin Neurons by Multiple GABA-Independent Mechanisms
}

\author{
Paulette B. Goforth, ${ }^{1}$ Gina M. Leinninger, ${ }^{3,4}$ Christa M. Patterson, ${ }^{3}$ Leslie S. Satin, ${ }^{1}$ and Martin G. Myers Jr ${ }^{2,3}$ \\ Departments of ${ }^{1}$ Pharmacology and ${ }^{2}$ Molecular and Integrative Physiology, and ${ }^{3}$ Division of Metabolism, Endocrinology, and Diabetes, Department of \\ Internal Medicine, University of Michigan, Ann Arbor, Michigan 48109, and ${ }^{4}$ Department of Physiology, Michigan State University, East Lansing, Michigan \\ 48824
}

The adipocyte-derived hormone leptin modulates neural systems appropriately for the status of body energy stores. Leptin inhibits lateral hypothalamic area (LHA) orexin (OX; also known as hypocretin)-producing neurons, which control feeding, activity, and energy expenditure, among other parameters. Our previous results suggest that GABAergic LHA leptin receptor (LepRb)-containing and neurotensin (Nts)-containing (LepRb ${ }^{\mathrm{Nts}}$ ) neurons lie in close apposition with OX neurons and control Ox mRNA expression. Here, we show that, similar to leptin, activation of LHA Nts neurons by the excitatory hM3Dq DREADD (designer receptor exclusively activated by designer drugs) hyperpolarizes membrane potential and suppresses action potential firing in OX neurons in mouse hypothalamic slices. Furthermore, ablation of LepRb from Nts neurons abrogated the leptin-mediated inhibition, demonstrating that LepRb ${ }^{\text {Nts }}$ neurons mediate the inhibition of $\mathrm{OX}$ neurons by leptin. Leptin did not significantly enhance $\mathrm{GABA}_{\mathrm{A}}$-mediated inhibitory synaptic transmission, and GABA receptor antagonists did not block leptin-mediated inhibition of OX neuron activity. Rather, leptin diminished the frequency of spontaneous EPSCs onto OX neurons. Furthermore, leptin indirectly activated an ATP-sensitive potassium $\left(\mathrm{K}_{\mathrm{ATP}}\right)$ channel in OX neurons, which was required for the hyperpolarization of OX neurons by leptin. Although Nts did not alter OX activity, galanin, which is coexpressed in LepRb ${ }^{\text {Nts }}$ neurons, inhibited OX neurons, whereas the galanin receptor antagonist M40 (galanin-(1-12)-Pro3-(Ala-Leu)2Ala amide) prevented the leptin-induced hyperpolarization of OX cells. These findings demonstrate that leptin indirectly inhibits OX neurons by acting on LHA LepRb ${ }^{\text {Nts }}$ neurons to mediate two distinct GABA-independent mechanisms of inhibition: the presynaptic inhibition of excitatory neurotransmission and the opening of $\mathrm{K}_{\mathrm{ATP}}$ channels.

Key words: EPSC; GABA; leptin; LHA; neurotensin; orexin

\section{Introduction}

The lateral hypothalamic area (LHA) receives and integrates many signals, including metabolic stimuli, to modulate feeding, activity, and attention/alertness as appropriate for current nutritional and environmental conditions (Morrison et al., 1958). The LHA contains several groups of neurons that contribute to these processes, including glutamatergic orexin (OX; also known as hypocretin)-containing cells that are activated by signals of en-

Received Dec. 10, 2013; revised June 18, 2014; accepted July 15, 2014.

Author contributions: P.B.G., G.M.L., C.M.P., L.S.S., and M.G.M. designed research; P.B.G., G.M.L., and C.M.P. performed research; P.B.G. and M.G.M. analyzed data; P.B.G., G.M.L., L.S.S., and M.G.M. wrote the paper.

This work was supported by the Animal Phenotyping Core of the Michigan Diabetes Research Center [National Institutes of Health (NIH) Grant P30 DK020572], the Michigan Nutrition and Obesity Research Center (NIH Grant P30 DK089503), the American Diabetes Association, the American Heart Association, the Marilyn H. Vincent Foundation (M.G.M.), and NIH Grants DK078056 (M.G.M.), DK090101 (G.M.L.), and DK46409 (L.S.S.). We thank Amylin Pharmaceuticals for the generous gift of leptin, Dr. Yuchio Yanagawa for OX-EGFP mice, Dr. Bryan Roth for CNO, and members of the Myers laboratory for helpful discussions.

Correspondence should be addressed to either of the following: Dr. Martin G Myers Jr, Departments of Internal Medicine and Physiology, University of Michigan, 1000 Wall Street, 6317 Brehm Tower, Ann Arbor, MI 48105, E-mail: mgmyers@umich.edu; or Dr. Leslie Satin, Department of Pharmacology, University of Michigan, 1000 Wall Street, 5128 Brehm Tower, Ann Arbor, Ml 48105, E-mail: Isatin@umich.edu.

DOI:10.1523/JNEUROSCI.5167-13.2014

Copyright $\odot 2014$ the authors $\quad 0270-6474 / 14 / 3411405-11 \$ 15.00 / 0$ ergy deficit. OX neurons project widely throughout the brain, including to monoaminergic targets in which OX-derived neuropeptides act at G-protein-coupled OX receptors 1 and 2 to inhibit sleep and to promote food seeking and vigilance (Toshinai et al., 2003; Yamanaka et al., 2003; Tsujino and Sakurai, 2009). Acute activation of the OX system, as by OX injection into the brain, triggers arousal and induces feeding (Lubkin and Stricker-Krongrad, 1998; Sakurai et al., 1998; Sweet et al., 1999; Jones et al., 2001; Perez-Leighton et al., 2012).

The hormone leptin, which is produced by adipocytes to signal the sufficiency of energy reserves, represents a crucial modulator of OX function. Leptin inhibits the firing of OX neurons (Yamanaka et al., 2003), and the drop in leptin levels during fasting activates OX neurons (Diano et al., 2003; Leinninger et al., 2011), increasing food seeking and alertness. Although the leptinmediated inhibition of OX neurons is central to the appropriate control of these neurons and their behavioral outputs (as well as to the physiologic and behavioral response to fasting), the mechanisms by which leptin modulates the activity of OX neurons has remained unclear.

Intermingled with OX neurons in the LHA is a distinct population of neurons that express the leptin receptor (LepRb) and 
that therefore respond to direct leptin action. Essentially all of these LHA LepRb neurons contain vesicular GABA transporter (vGAT) and GAD1 (Leinninger et al., 2009; Vong et al., 2011), suggesting that they may act in part by releasing GABA; many $(\sim 60 \%)$ also contain the neuropeptide neurotensin (Nts) (Leinninger et al., 2011). We demonstrated previously that LHA LepRb neurons and LHA Nts neurons lie in close contact with OX cells and that LHA leptin action modulates $O x$ mRNA expression, suggesting that leptin may control OX neuron activity via Nts-containing LHA LepRb $\left(\right.$ LepRb ${ }^{\mathrm{Nts}}$ neurons; Leinninger et al., 2011). However, the cellular mechanisms that underlie leptin-dependent regulation of OX neurons remain unclear. Here, we use the electrophysiological analysis of OX neuron function to directly demonstrate the importance of LepRb ${ }^{\mathrm{Nts}}$ neurons for the control of OX cells and to elucidate the mechanisms by which leptin inhibits OX neurons.

\section{Materials and Methods}

Animals. All procedures were approved by the University of Michigan University Committee on the Use and Care of Animals in accordance with Association for Assessment and Accreditation of Laboratory Animal Care and National Institutes of Health guidelines. Animals were bred at the University of Michigan and main-

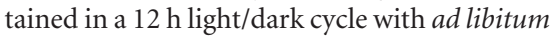
access to food and water. Transgenic mice expressing enhanced green fluorescent protein (EGFP) under the control of the human prepro-orexin promoter (OX-EGFP mice; Sakurai et al., 1999; Li et al., 2002) were a generous gift from Yuchio Yanagawa (Gunma University, Gunma, Japan). $N s^{c r e}$ and Lepr $^{N t s} \mathrm{KO}$ mice (as described previously; Leinninger et al., 2011) were bred onto the OX-EGFP background for electrophysiology experiments.

DREADD activation of LHA Nts neurons. AAV-Flex-hM3DqmCherry virus (Alexander et al., 2009) was purchased from the UNC Vector Core (University of North Carolina, Chapel Hill, NC). Virus was stereotaxically injected bilaterally into the LHA of $\mathrm{Nts}^{\mathrm{cre}}$; OX-EGFP mice at 5-6 weeks of age. Mice were administered presurgical analgesic, anesthetized using isoflurane, and placed in a stereotaxic frame. After exposing the skull, a guide cannula with a stylet (Plastics One) was lowered into the target regions. Coordinates to the LHA (from bregma) were as follows: anteroposterior, $-1.34 \mathrm{~mm}$; mediolateral, $-1.12 \mathrm{~mm}$; and dorsoventral, $-5.20 \mathrm{~mm}$, in accordance with the atlas of Paxinos and Franklin (2001). The stylet was removed and replaced by an injector, and $250 \mathrm{nl}$ of virus was injected to the LHA using a $500 \mathrm{nl}$ Hamilton syringe at a rate of $50 \mathrm{nl} / 30 \mathrm{~s}$. After $5 \mathrm{~min}$, the injector and cannula were removed from the skull, and the incision was sutured.

After 1 week recovery, animals were killed for electrophysiological analysis of OX neuron function. Stereotaxic injection sites were confirmed by visualization of mCherry fluorescence in the LHA of slices used for electrophysiological recording. Mice were only included for study if DREADD-mCherry-expressing cell bodies were confined to the LHA.

Electrophysiological recordings. Four- to 7-week-old mice of either sex were killed by decapitation, and $250 \mu \mathrm{m}$ coronal slices were prepared using a VT 1200 S vibratome (Leica) in oxygenated ice-cold sucrose so- lution containing the following (in $\mathrm{mm}$ ): 220 sucrose, $2.5 \mathrm{KCl}, 26$ $\mathrm{NaHCO}_{3}, 1.25 \mathrm{NaH}_{2} \mathrm{PO}_{4}, 5$ glucose, $6 \mathrm{MgCl}_{2}$, and $1 \mathrm{CaCl}_{2}$. Slices were allowed to recover for at least $1 \mathrm{~h}$ in a holding chamber containing oxygenated artificial CSF (aCSF) solution containing the following (in mM): $130 \mathrm{NaCl}, 3 \mathrm{KCl}, 1.25 \mathrm{NaH}_{2} \mathrm{PO}_{4}, \mathrm{NaHCO}_{3}, 5$ glucose, $1 \mathrm{MgCl}_{2}$, and 2.5 $\mathrm{CaCl}_{2}, \mathrm{pH} 7.4$, before electrophysiological analysis. Electrophysiological parameters were measured from individual OX-EGFP neurons in the LHA visualized using an Olympus BX51WI upright microscope equipped with infrared differential interference contrast optics (Olympus). Patch electrodes made from borosilicate glass capillaries (Warner Instruments) were pulled to a tip resistance of 3-7 M $\Omega$ using a Brown/ Flaming P-97 micropipette puller (Sutter Instruments) and filled with a solution containing the following (in $\mathrm{mm}$ ): $130 \mathrm{~K}$-gluconate, $10 \mathrm{KCl}, 1$ EGTA, 10 HEPES, 0.6 NaGTP, $2 \mathrm{MgATP}$, and 8 phosphocreatine, $\mathrm{pH}$ 7.2. In a subset of experiments, intracellular ATP was increased to $5 \mathrm{~mm}$ by the addition of $3 \mathrm{~mm} \mathrm{~K}_{2} \mathrm{ATP}$. Results obtained from neurons dialyzed with $5 \mathrm{~mm}$ intracellular ATP did not differ from those filled with $2 \mathrm{~mm}$ ATP; therefore, both groups were pooled for analysis. Slices were superfused with aCSF solution warmed to $34^{\circ} \mathrm{C}$ using a TC-344 temperature controller and preheater (Warner Instruments) and continuously bubbled with $5 \% \mathrm{CO}_{2}$ and $95 \% \mathrm{O}_{2}$. Drugs were applied via bath perfusion. Data shown are not adjusted for a liquid junction potential of $14.7 \mathrm{mV}$. Whole-cell currents and membrane potentials were measured using tight-seal whole-cell voltage- or current-clamp (Hamill et al., 1981) using an Axopatch 200B amplifier (Molecular Devices). Currents were filtered at $2 \mathrm{kHz}$, digitized at $5 \mathrm{kHz}$, and analyzed offline. Neurons selected for analysis had stable series resistances $<25 \mathrm{M} \Omega$ that were not compen- 

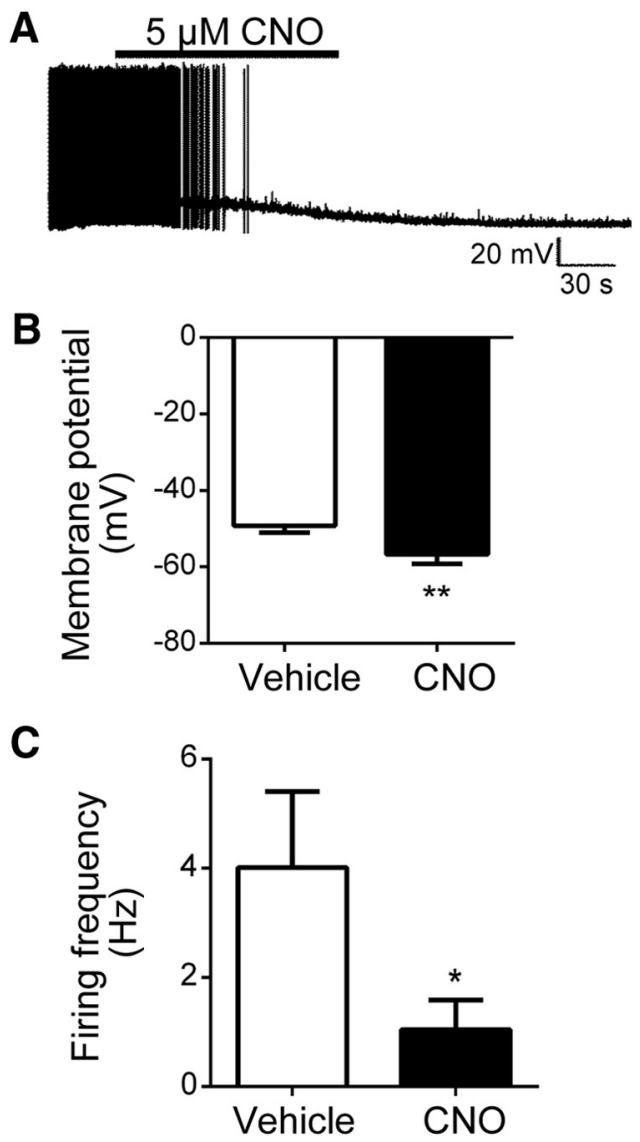

Figure 2. Selective stimulation of LHA Nts neurons via activation of the excitatory DREADD, hM3Dq, inhibits $0 \mathrm{X}$ neuron activity. $A$, Current-clamp recording depicting CNO-induced membrane hyperpolarization in an individual OX neuron from a mouse expressing hM3Dq in LHA Nts neurons. Acute CNO application significantly reduced mean OX neuron membrane potential ( $\boldsymbol{B}$; $\left.n=12,{ }^{* *} p<0.01\right)$ and suppressed mean action potential firing in $0 \mathrm{X}$ neurons $(\boldsymbol{C} ; n=12$, $\left.{ }^{*} p<0.05\right)$.

sated. Spontaneous EPSCs (sEPSCs) and sIPSCs were measured from neurons voltage clamped to $-50 \mathrm{mV}$ using standard intracellular and aCSF solutions. At this voltage, sEPSCs are inward currents and sIPSCs are outward currents. sIPSCs were also recorded from neurons voltage clamped to $-65 \mathrm{mV}$ in the presence of the glutamate receptor antagonists 6-cyano-7-nitroquinoxaline-2,3-dione (CNQX; $10 \mu \mathrm{M}$ ) and D-(-)-2-amino-5-phosphonopentanoic acid (APV; $20 \mu \mathrm{M})$ and using an intracellular solution containing the following (in $\mathrm{mM}$ ): 140 $\mathrm{KCl}, 1$ EGTA, 10 HEPES, $0.6 \mathrm{NaGTP}, 2 \mathrm{MgATP}$, and 8 phosphocreatine. Current-voltage $(I-V)$ curves were generated using a voltage ramp command ( -120 to $+40 \mathrm{mV}$ ) and whole-cell conductance calculated from the slope of the current elicited from -100 to $-50 \mathrm{mV}$. Leptin-elicited difference currents were plotted versus clamp voltage.

Data analysis and statistics. sEPSC and sIPSC events were analyzed using a commercial software package (Synaptosoft). Individual events were detected using an amplitude threshold value set at $10 \mathrm{pA}$ and confirmed visually. Event amplitude, interevent interval, 10$90 \%$ rise time, and half-width were determined before and after drug treatments. Statistical comparisons of cumulative probability distributions were made with MATLAB using the nonparametric Kolmogorov-Smirnov test, and significance was defined as $p<0.001$. All other statistical analyses were performed using GraphPad Prism 5.0 (GraphPad Software), and statistical significance was determined using Student's $t$ test for comparison of two groups or ANOVA and Tukey's multiple comparison post hoc test for comparison of multiple groups. Statistical differences were defined as $p<0.05$. Error bars shown depict mean \pm SEM.
Chemicals and reagents. Leptin was a generous gift from Amylin Pharmaceuticals. Galanin (Gal) and Nts were purchased from American Peptide. CNQX, APV, M40 (galanin-(1-12)-Pro3-(Ala-Leu)2Ala amide), and CGP52432 (3-[[(3,4-dichlorophenyl)-methyl] amino]propyl](diethoxymethyl)phosphinic acid) were purchased from R\&D Systems. Bicuculline methiodide (BMI) and tolbutamide were purchased from Sigma. Clozapine- $N$-oxide $(\mathrm{CNO})$ was a generous gift from Dr. Bryan Roth (University of North Carolina, Chapel Hill, NC). All drugs were made as stock solutions (tolbutamide and CGP52432 in DMSO) and freshly diluted in aCSF for recording. Drug treatments were compared with vehicle control.

\section{Results \\ Leptin inhibits the activity of OX neurons via LepRb ${ }^{\text {Nts }}$ neurons}

To examine the mechanisms by which leptin modulates OX neurons, we used transgenic mice expressing EGFP under the control of the human prepro-orexin promoter (Sakurai et al., 1999), permitting the visualization of OX-EGFP neurons in acute slice preparations for electrophysiological recordings. We assessed the electrical activity of OX-EGFP neurons in the LHA of hypothalamic slices using whole-cell patch-clamp recordings in currentclamp mode to measure membrane potential and action potential firing. As shown previously, acute leptin (10 nM) hyperpolarized OX neuron membrane potential (Fig. $1 A, B$; control, $-51.0 \pm 1.1 \mathrm{mV}$; leptin, $-58.6 \pm 1.7 \mathrm{mV} ; p<0.0001, t_{(30)}=$ 5.16) and reduced action potential firing (Fig. $1 C$; control, $5.4 \pm$ $0.7 \mathrm{~Hz}$; leptin, $\left.1.3 \pm 0.4 \mathrm{~Hz} ; p<0.0001, t_{(19)}=5.34\right)$. Leptin action progressed over several minutes with the initial response and maximal hyperpolarization occurring $77 \pm 10$ and $265 \pm 34 \mathrm{~s}$ after the start of leptin treatment, respectively. Leptin did not significantly alter action potential amplitude, 10-90\% rise time, half-width, or firing threshold (data not shown).

Leptin hyperpolarized membrane potential by $\geq 5 \mathrm{mV}$ in $68 \%$ (21 of 31 ) of the cells examined, and the effect was reversible in $53 \%$ of responders (Fig. $1 D$; control, $-51.3 \pm 1.9 \mathrm{mV}$; leptin, $-62.4 \pm 2.3 \mathrm{mV}$; wash, $-56.9 \pm 2.8 \mathrm{mV} ; p<0.0001, F_{(2,32)}=$ 14.77). However, the reduction in spike frequency only partially reversed in $29 \%$ of neurons during a wash period of $10-30 \mathrm{~min}$ (Fig. $1 E$; control, $5.9 \pm 0.8 \mathrm{~Hz}$; leptin, $1.3 \pm 0.5 \mathrm{~Hz}$; wash, $1.8 \pm$ $\left.0.6 \mathrm{~Hz} ; p<0.0001, F_{(2,32)}=24.18\right)$, consistent with the long-term effects of leptin and previous observations in other systems. It should be noted that these percentages are based on recordings from GFP-identified cells in a transgenic model that labels only a subset of OX neurons (Sakurai et al., 1999).

Although OX neurons themselves do not express LepRb (Leinninger et al., 2009; Louis et al., 2010; Laque et al., 2013), our previous studies reveal that LHA LepRb and LHA Nts neurons lie in close contact with OX neurons (Louis et al., 2010; Leinninger et al., 2011). We thus hypothesized that leptin indirectly modulates OX neuron function via action at presynaptic LHA LepRb ${ }^{\mathrm{Nts}}$ neurons (neurons that coexpress LepRb and Nts are restricted to the LHA). Indeed, deletion of LepRb from LepRb ${ }^{\mathrm{Nts}}$ neurons in $L e \mathrm{pr}^{\mathrm{Nts}} \mathrm{KO}$ mice prevents the accumulation of c-Fos in OX neurons during fasting, as well as the modulation of $O x$ mRNA by leptin (Leinninger et al., 2011). To examine the functional connectivity between LHA Nts neurons and OX neurons, we used a recombinant adeno-associated virus (AAV) that mediates the cre-dependent expression of DREADDs (designer receptors exclusively activated by designer drugs; expressed as DREADD-mCherry fusion proteins), which are genetically engineered muscarinic receptor variants that are insensitive to endogenous ligands but are activated by the otherwise biologically inert agonist $\mathrm{CNO}$. CNO activates neurons containing the $\mathrm{G}_{\mathrm{q}}$-coupled 
DREADD, hM3Dq (Armbruster et al., 2007; Alexander et al., 2009; Krashes et al., 2011).

Thus, the injection of the cre-inducible DREADD-mCherry AAV into the LHA of $N t s^{\text {cre }}$ mice will promote the expression of hM3Dq specifically in LHA Nts neurons.

We injected the cre-inducible hM3Dq virus into the LHA of $N t^{\text {cre }}$ animals on the $O X-E G F P$ background to permit the electrophysiological examination of OX neurons during the selective activation of LHA Nts cells. In this system, acute CNO (5 $\mu \mathrm{M}$ ) application to hypothalamic slices from animals expressing hM3Dq DREADDs in LHA Nts neurons hyperpolarized membrane potential in $50 \%$ (6 of 12) of OX neurons (Fig. $2 A, B$; control, $-49.2 \pm 1.8, \mathrm{CNO},-56.7 \pm 2.5 ; p=$ $\left.0.003, t_{(11)}=3.80\right)$ and decreased their action potential firing (Fig. $2 C$; control, $4.0 \pm 1.4 \mathrm{~Hz}$; $\mathrm{CNO}, 1.0 \pm 0.5 \mathrm{~Hz} ; p=$ $\left.0.04, t_{(8)}=1.98\right)$, similar to the results observed with acute leptin treatment. This suggests that LHA Nts neurons are functionally afferent to OX neurons, and the activation of LHA Nts neurons inhibits OX neurons. Note that, although we could not confine DREADD expression to LepRb $^{\text {Nts }}$ neurons specifically, DREADD expression in LHA Nts neurons includes LepRb ${ }^{\mathrm{Nts}}$ neurons (as well as non-LepRb Nts cells in the LHA), suggesting that LepRb ${ }^{\mathrm{Nts}}$ neurons may mediate the inhibition of OX neurons by leptin. Importantly, because leptin (like the hM3Dq DREADD) presumably activates LepRb ${ }^{\text {Nts }}$ cells (Leinninger et al., 2011), the inhibition of OX neurons by activation of LHA Nts cells is consistent with the potential role for leptin action on LepRb ${ }^{\mathrm{Nts}}$ cells in the suppression of OX neuron activity.

To directly examine leptin regulation of OX neurons by LepRb ${ }^{\text {Nts }}$ neurons, we bred $N t s^{\text {cre }}$;Lepr ${ }^{\text {flox/flox }}\left(\mathrm{Lepr}^{\mathrm{Nts}} \mathrm{KO}\right)$ mice onto the OX-EGFP background to identify and record from OX neurons in hypothalamic slices of animals lacking leptin receptors in LHA Nts neurons. The effects of leptin that we observed in control animals was attenuated in Lepr $^{N \text { Nts }} \mathrm{KO}$ mice. Although the basal membrane potential and action potential frequency of $\mathrm{OX}$ neurons did not differ between Lepr ${ }^{N t s} \mathrm{KO}$ mice and littermate controls, leptin failed to modulate activity in most OX neurons of Lepr ${ }^{N t s} \mathrm{KO}$ mice (Fig. 3A). Although leptin hyperpolarized ( $\geq 5 \mathrm{mV}$ ) $78 \%$ of OX neurons (seven of nine) from control mice (Fig. $3 B$; control, $-51.6 \pm 1.1 \mathrm{mV}$; leptin, $-61.1 \pm 3.0 \mathrm{mV} ; p=0.008, t_{(8)}=$ 3.50 ), leptin action was significantly diminished in Lepr $^{N t s} \mathrm{KO}$ mice because only
A

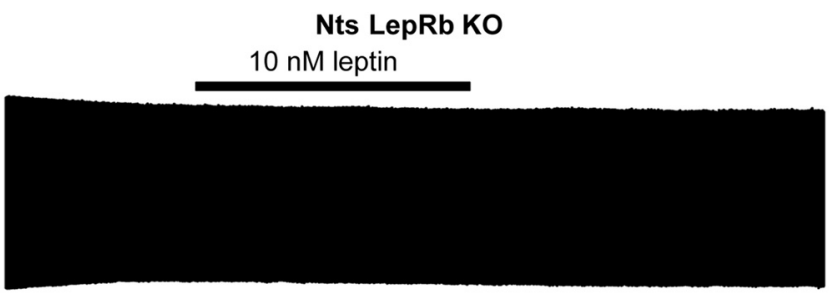

B

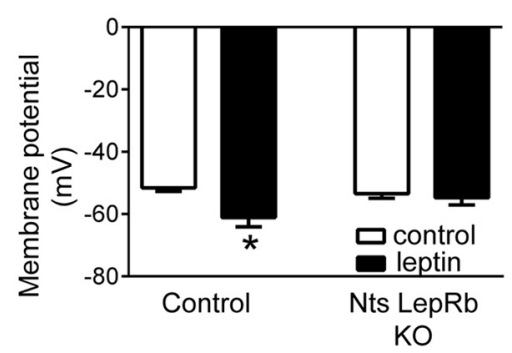

$20 \mathrm{mV} \bigsqcup_{60 \mathrm{~s}}$

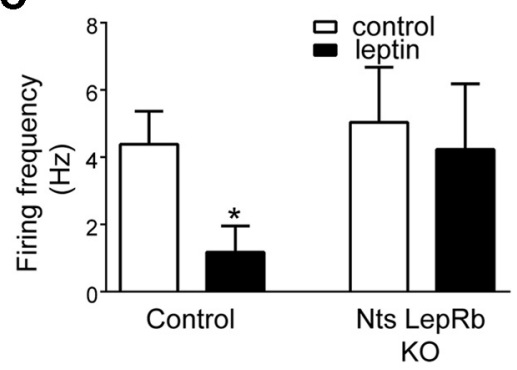

Figure 3. LepRb deletion from LHA Nts neurons attenuates leptin-induced suppression of OX neuron activity. $\boldsymbol{A}$, Current-clamp recordings of membrane potential from an individual $\mathrm{OX}$ neuron in a brain slice preparation from Nts LepRb KO mice show reduced responsiveness to acute leptin. Acute leptin treatment of brain slices from Nts LepRb KO mice did not significantly alter mean $0 \mathrm{X}$ neuron membrane potential $(\boldsymbol{B})$ or mean action potential firing $\left(\boldsymbol{C} ; n=9,{ }^{*} p<0.05\right.$ for control and $n=10, p>0.05$ for KO).

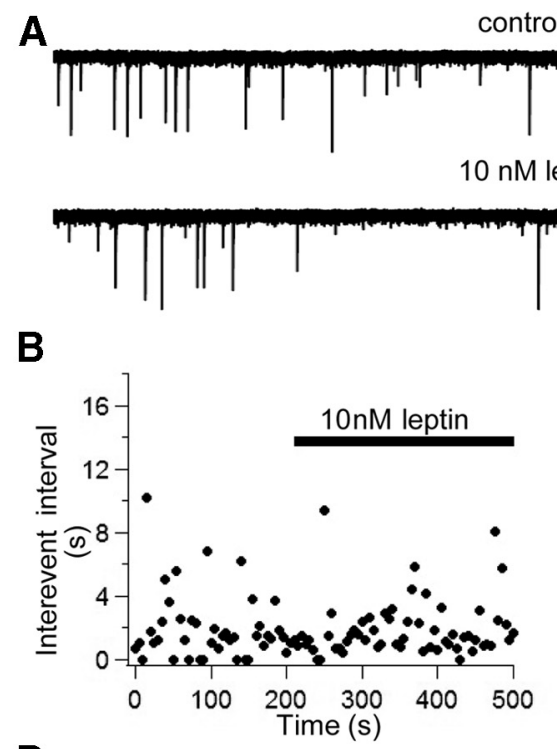

D

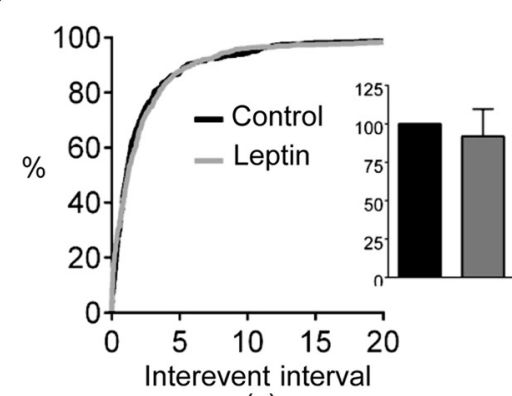

(s)

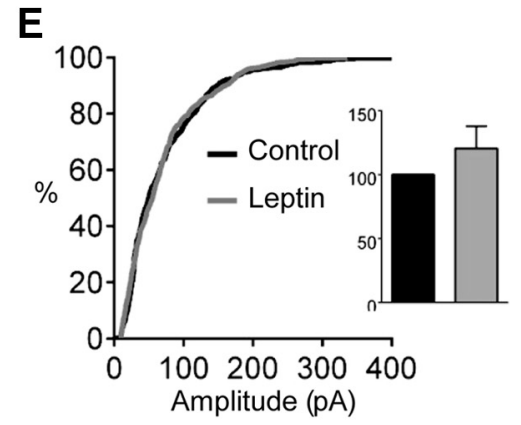

Figure 4. Leptin does not enhance GABA-mediated synaptic input to OX neurons. A, Voltage-clamp recording of sIPSCs (downward deflections) from an individual $0 X$ neuron, clamped to $-65 \mathrm{mV}$ with symmetrical intracellular/extracellular $\mathrm{Cl}^{-}$, before and after acute leptin treatment. Time course of average sIPSC interevent interval (B) and sIPSC amplitude in response to leptin ( $\boldsymbol{C}$. Although subsets of OX neurons displayed either increased or decreased SIPSC frequency and/or sIPSC amplitude in response to leptin, cumulative probability distributions for control (black line) and leptin (gray line) reveal no overall shift in sIPSC interevent interval ( $\boldsymbol{D}$; inset mean normalized sIPSC frequency) or sIPSC amplitude ( $\boldsymbol{E}$; inset: mean normalized SIPSC amplitude). $n=7, p>0.05$. 
A
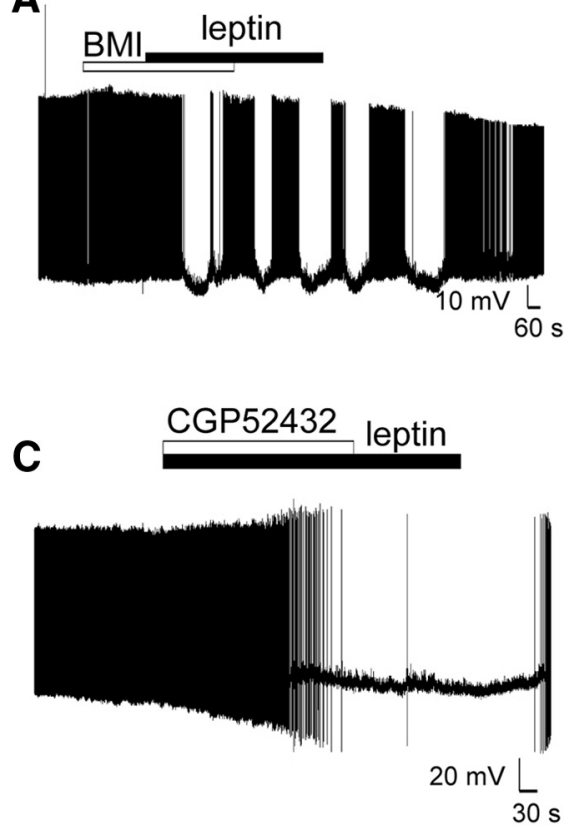

B

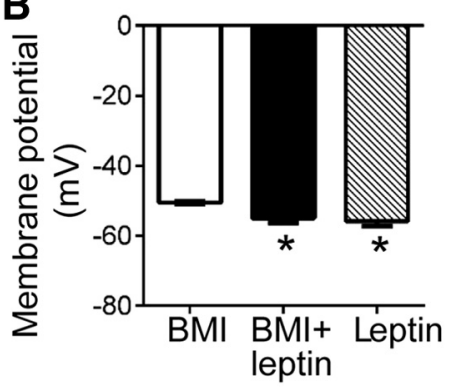

\section{D}

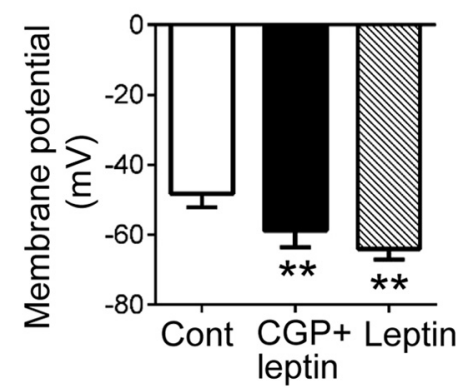

Figure 5. GABA receptor antagonists do not prevent leptin-induced inhibition of $0 \mathrm{X}$ neurons. $A$, Current-clamp recording of membrane potential in an individual neuron in response to coapplication of BMI ( $30 \mu \mathrm{M}$ ) plus leptin (10 nM). $\boldsymbol{B}$, Leptin significantly hyperpolarized mean resting $0 \mathrm{X}$ membrane potential in the presence of $\mathrm{BMI}\left(n=7,{ }^{*} p<0.05\right.$ for BMI plus leptin and leptin only vs BMI). C, Current-clamp recording of membrane potential in an individual neuron in response to coapplication of CGP52432 (10 $\mu \mathrm{M})$ plus leptin $(10 \mathrm{nM})$. D, Leptin significantly hyperpolarized mean resting 0 X membrane potential in the presence of CGP52432 ( $n=3,{ }^{* *} p<0.01$ for (GP plus leptin and leptin only vs vehicle control).

20\% (2 of 10) of OX neurons exhibited leptin-induced hyperpolarization, with no significant decrease in mean membrane potential (control, $-53.4 \pm 1.5 \mathrm{mV}$; leptin, $-54.8 \pm 2.2 \mathrm{mV} ; p=$ $\left.0.45, t_{(9)}=0.79\right)$. Similarly, leptin reduced action potential firing in OX neurons from control mice (Fig. $3 C$; control, $4.4 \pm 1.0 \mathrm{~Hz}$; leptin, $\left.1.2 \pm 0.8 \mathrm{~Hz} ; p=0.0007, t_{(8)}=5.39\right)$ but had no significant effect on the firing of OX neurons from Lepr $_{N t s} \mathrm{KO}$ mice (control, $5.0 \pm 1.6 \mathrm{~Hz}$; leptin, $4.2 \pm 2.0 \mathrm{~Hz} ; p=0.32, t_{(9)}=1.05$ ). Thus, LHA-restricted LepRb ${ }^{\mathrm{Nts}}$ neurons play an important role in the modulation of OX neuron activity by leptin, consistent with the blunted activation of OX neurons observed during fasting in eepr $^{\text {Nts }} \mathrm{KO}$ mice (Leinninger et al., 2011).

\section{GABA-independent inhibition of OX neurons by leptin}

LHA LepRb neurons express GAD1 and vGat, consistent with the GABAergic nature of these cells (Leinninger et al., 2009; Vong et al., 2011) and suggesting that leptin might inhibit OX neurons by the direct release of GABA onto OX cells. Indeed, application of the $\mathrm{GABA}_{\mathrm{A}}$ receptor agonist muscimol or the $\mathrm{GABA}_{\mathrm{B}}$ receptor agonist baclofen hyperpolarizes OX neurons (Xie et al., 2006; Matsuki et al., 2009), demonstrating that GABA signaling can inhibit OX neurons.

Therefore, we assessed the effect of leptin on GABA-mediated inhibitory synaptic transmission by measuring sIPSCs from OX neurons voltage clamped to $-65 \mathrm{mV}$ in the presence of the glutamate receptor blockers APV $(20 \mu \mathrm{M})$ and CNQX $(10 \mu \mathrm{M})$ and using symmetrical intracellular and extracellular $\mathrm{Cl}^{-}$. These conditions produced inward sIPSCs that were completely abolished by the $\mathrm{GABA}_{\mathrm{A}}$ antagonist BMI (30 $\mu \mathrm{M}$; data not shown), confirming their mediation by $\mathrm{GABA}_{\mathrm{A}}$ receptors. Mean sIPSC frequency was $0.57 \pm 0.13 \mathrm{~Hz}$ (range, $0.09-1.02 \mathrm{~Hz}$ ). Mean sIPSC amplitude was $53.4 \pm 9.4 \mathrm{pA}$ (range, 29.2-99.4 pA). This relatively low frequency of sIPSCs at baseline is consistent with previous observations (Horvath and Gao, 2005). Leptin variably affected the sIPSCs of OX neurons, with a subset of neurons exhibiting enhanced sIPSC frequency (three of seven) and/or amplitude (three of seven) and a subset having decreased sIPSC frequency (four of seven) and/or amplitude (three of seven; Fig. 4). Overall, we observed no significant differences in sIPSC frequency or amplitude in the presence of leptin that could account for leptin-induced inhibition of OX activity that we observed. Thus, leptin neither shifted the cumulative distribution of sIPSC amplitude or interevent interval (Fig. 4D,E) nor altered mean normalized sIPSC frequency (Fig. 4D, inset; $92 \pm 18 \%$ of control, $\left.p=0.13, t_{(6)}=1.75\right)$ or amplitude (Fig. $4 E$, inset; $121 \pm 17 \%$ of control, $\left.p=0.28, t_{(6)}=1.19\right)$. These findings suggest that, although LepRb ${ }^{\text {Nts }}$ neurons may synthesize and package GABA into vesicles, increased GABA-mediated synaptic transmission onto OX neurons is unlikely to underlie leptin-induced OX neuron inhibition.

Furthermore, leptin-induced OX inhibition persisted in the presence of the selective $\mathrm{GABA}_{\mathrm{A}}$ or $\mathrm{GABA}_{\mathrm{B}}$ receptor antagonists BMI $(30 \mu \mathrm{M})$ and CGP52432 $(10 \mu \mathrm{M})$, respectively (Fig. 5). Leptin-induced hyperpolarization of OX membrane potential persisted in the presence of BMI (BMI, $-50.1 \pm 0.5$; BMI plus leptin, $-55.0 \pm 1.3$; leptin only, $-55.8 \pm 1.5 \mathrm{mV}$; Fig. $5 A, B, p=$ $\left.0.003, F_{(2,12)}=9.69\right)$, with a subset of neurons displaying intermittent bursts of activity during treatment with BMI plus leptin (Fig. 5A), likely attributable to changes in excitatory/inhibitory balance caused by BMI. Similarly, CGP52432, which occludes baclofen-induced (and $\mathrm{GABA}_{\mathrm{B}}$-mediated) inhibition of $\mathrm{OX}$ activity (Xie et al., 2006), did not prevent leptin-induced hyperpolarization of OX neurons (control, $-48.3 \pm 3.8$; CGP52432 plus leptin, $-58.8 \pm 4.7$; leptin only, $-64.0 \pm 3.1 \mathrm{mV}$; Fig. $5 C, D, p=$ $\left.0.006, F_{(2,4)}=25.01\right)$.

Leptin suppresses excitatory synaptic input onto OX neurons Excitatory input to OX neurons is substantially greater than inhibitory input to OX cells, and the excitatory input is modulated by a variety of stimuli (Li et al., 2002; Acuna-Goycolea and van den Pol, 2004; Acuna-Goycolea et al., 2004; Fu et al., 2004; Horvath and Gao, 2005; Liu and Gao, 2007; Rao et al., 2007, 2013), including short-term (24 h) fasting (Horvath and Gao, 2005), which decreases circulating leptin concentrations. To investigate whether leptin modulates excitatory input to OX neurons, we recorded sEPSCs in OX-EGFP neurons, voltage clamped to -50 $\mathrm{mV}$, before and after the application of leptin (10 nM). At -50 $\mathrm{mV}$, sIPSCs and sEPSCs mediate outward and inward currents, respectively, under our recording conditions (Fig. 6A). sEPSCs (inward currents) were blocked by APV $(20 \mu \mathrm{M})$ and CNQX (10 $\mu \mathrm{M}$ ), confirming their mediation by glutamate receptors (data not shown). Mean sEPSC frequency was $4.2 \pm 0.8 \mathrm{~Hz}$ (range, $0.9-14.4 \mathrm{~Hz}$ ), and mean sEPSC amplitude was $22.6 \pm 1.6 \mathrm{pA}$ 
(range, 12.8-42.3 pA). Acute leptin significantly decreased sEPSC frequency (14 of 18 neurons), manifested as a prolongation (rightward shift) of sEPSC interevent interval, but had no effect on the sEPSC amplitude distribution (Fig. 6B-E). Likewise, leptin decreased mean normalized sEPSC frequency (Fig. $6 D$, inset; $68.3 \pm$ $8.1 \%$ of control, $p=0.001, t_{(17)}=3.92$ ) but did not alter mean normalized sEPSC amplitude (Fig. $6 E$, inset; $99.8 \pm 3.5 \%$ of control, $\left.p=0.93, t_{(17)}=0.09\right)$. Leptin did not alter sEPSC rise time, half-width, or charge transfer (data not shown). The specific decrease in sEPSC frequency suggests leptin-induced alterations in presynaptic glutamate release rather than changes in postsynaptic glutamate receptor function.

The pharmacologic activation of $\mathrm{GABA}_{\mathrm{B}}$ receptors can inhibit presynaptic glutamate release onto OX neurons (resulting in reduced sEPSC frequency but not amplitude). Thus, GABA release from LHA LepRb neurons could theoretically act presynaptically on $\mathrm{GABA}_{\mathrm{B}}$ receptors to decrease sEPSC frequency onto OX neurons. Therefore, we tested the ability for the $\mathrm{GABA}_{\mathrm{B}}$ antagonist CGP52432 to ameliorate leptin-induced suppression of sEPSC frequency in OX neurons. As shown in Figure 6F, CGP52432 had no significant effect on the leptin-induced decrease in sEPSC frequency (normalized frequency: leptin, $63.8 \pm 9.5 \%$ of control; leptin plus CGP52432, $74.9 \pm 11.9 \%$ of control; $\left.p=0.007, F_{(2,10)}=8.45\right)$. This finding is consistent with the failure of CGP52432 to reverse the leptin-induced hyperpolarization of OX neurons (Fig. $5 C, D)$ and with a GABA-independent mechanism of OX regulation by leptin.

Leptin elicits $\mathrm{K}_{\mathrm{ATP}}$ channel activation in OX neurons

In addition to suppressing excitatory transmission, leptin decreased the input resistance of OX neurons measured in current clamp (data not shown). Indeed, leptin elicited an outward current in 68\% (13 of 19) of OX neurons voltage clamped to $-50 \mathrm{mV}$, with a mean amplitude of $24.7 \pm 9.2 \mathrm{pA}$ (Fig. $7 A$ ). To identify the channel(s) underlying this current, we used voltage ramp protocols to generate $I-V$ relationships in the presence and absence of leptin (10 nM) and calculated leptin-elicited difference currents. As shown in Figure 7, $B$ and $C$, leptin activated a current that exhibited a leftward shift in reversal potential and significantly increased whole-cell conductance compared with controls (Fig. $7 D$; control, $1.3 \pm 0.2 \mathrm{nS}$; leptin, $2.3 \pm 0.3 \mathrm{nS} ; p=0.0003, t_{(16)}=$ 4.58). The mean reversal potential of leptin-activated difference currents, $-94.3 \pm 3.5 \mathrm{mV}$ (adjusted here for liquid junction potential) was near the calculated $\mathrm{K}^{+}$equilibrium potential of

$\mathbf{F}$
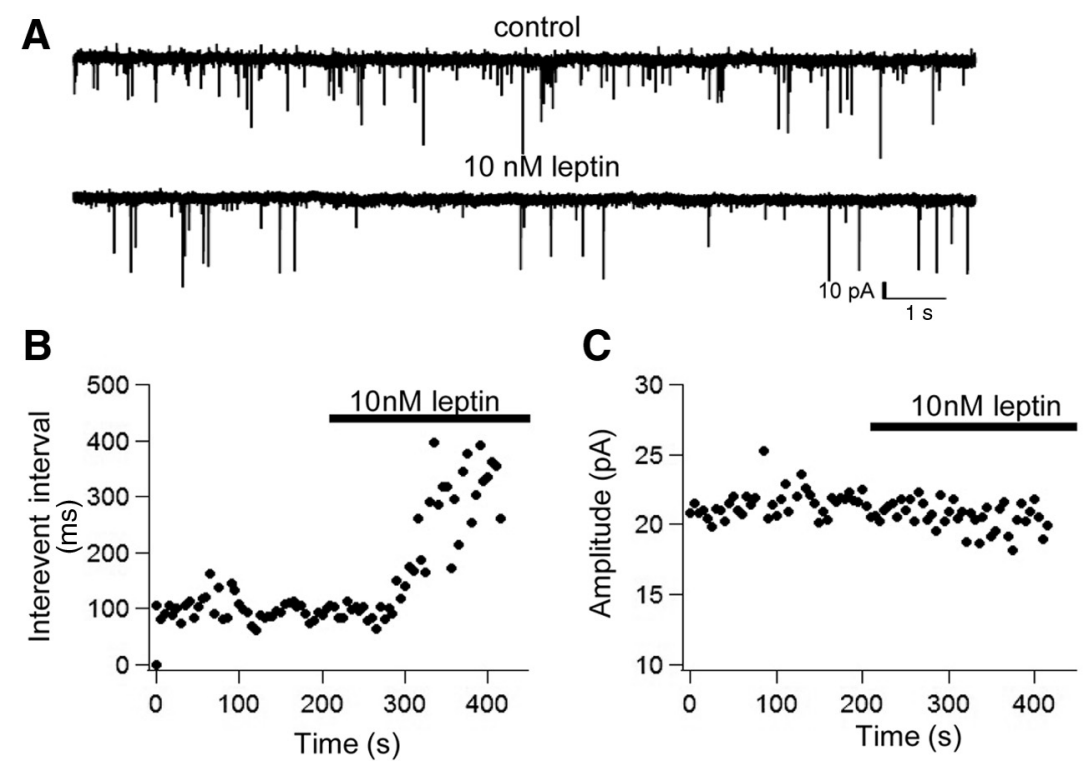

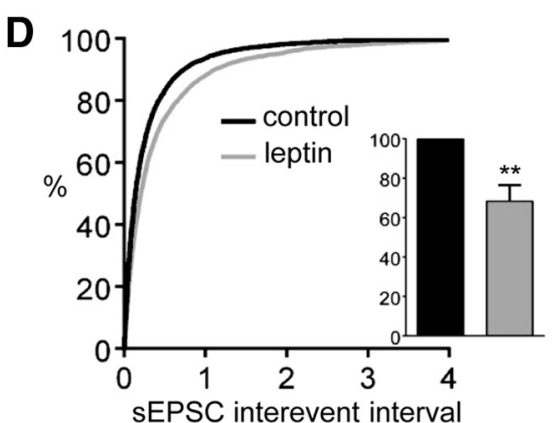

(s)

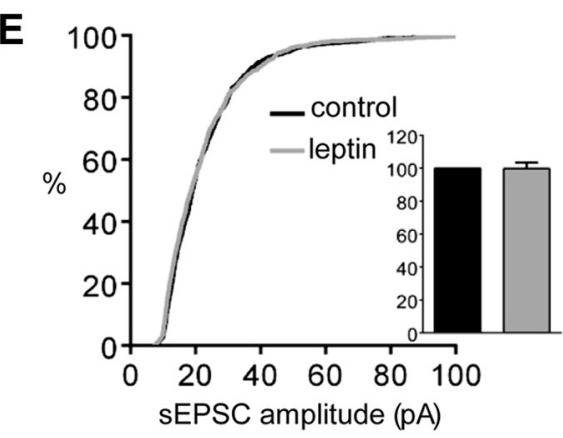

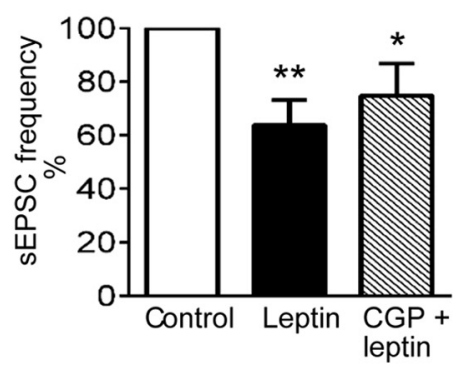

Figure 6. Leptin suppresses sEPSC input to OX neurons. $\boldsymbol{A}$, Voltage-clamp recording of sEPSCS (downward deflections) from an individual $\mathrm{OX}$ neuron, clamped to $-50 \mathrm{mV}$ before and after acute leptin treatment. Time course of average sEPSC interevent interval $(\boldsymbol{B})$ and sEPSC amplitude in response to leptin (C). D, Leptin decreased sEPSC frequency, as indicated by a rightward shift of the cumulative probability distribution of $s$ EPSC interevent interval $\left(n=18,{ }^{* *} p<0.001\right)$ and a significant reduction of mean normalized sEPSC frequency (inset: $n=18, p<0.01$ ). $\boldsymbol{E}$, Leptin did not significantly alter the distribution of sEPSC event amplitudes or mean normalized sEPSC amplitude (inset; $n=18, p>0.05$ ). $\boldsymbol{F}$, Coapplication of (GP52432 did not reverse leptin-induced suppression of sEPSC frequency, indicated by a significant reduction in mean normalized sEPSC frequency in the presence of leptin $\left(n=6,{ }^{* *} p<0.01\right)$ and leptin plus CGP52432 $\left(n=6,{ }^{*} p<0.05\right)$.

$-101 \mathrm{mV}$ for the recording solutions we used, strongly suggesting activation of a $\mathrm{K}^{+}$channel. OX neurons possess a multitude of potassium channels capable of producing a similar degree of hyperpolarization to that observed with leptin, including ATPsensitive potassium $\left(\mathrm{K}_{\text {АTP }}\right)$ channels, and the opening of OX $\mathrm{K}_{\mathrm{ATP}}$ channels generates currents having similar rectification, reversal potential, and conductance as observed for leptin-elicited current (Parsons and Hirasawa, 2010; Liu et al., 2011; Parsons et al., 2012a,b; Karnani et al., 2011). Therefore, we tested the sensitivity of the leptin-elicited current to the selective $\mathrm{K}_{\mathrm{ATP}}$ blocker 

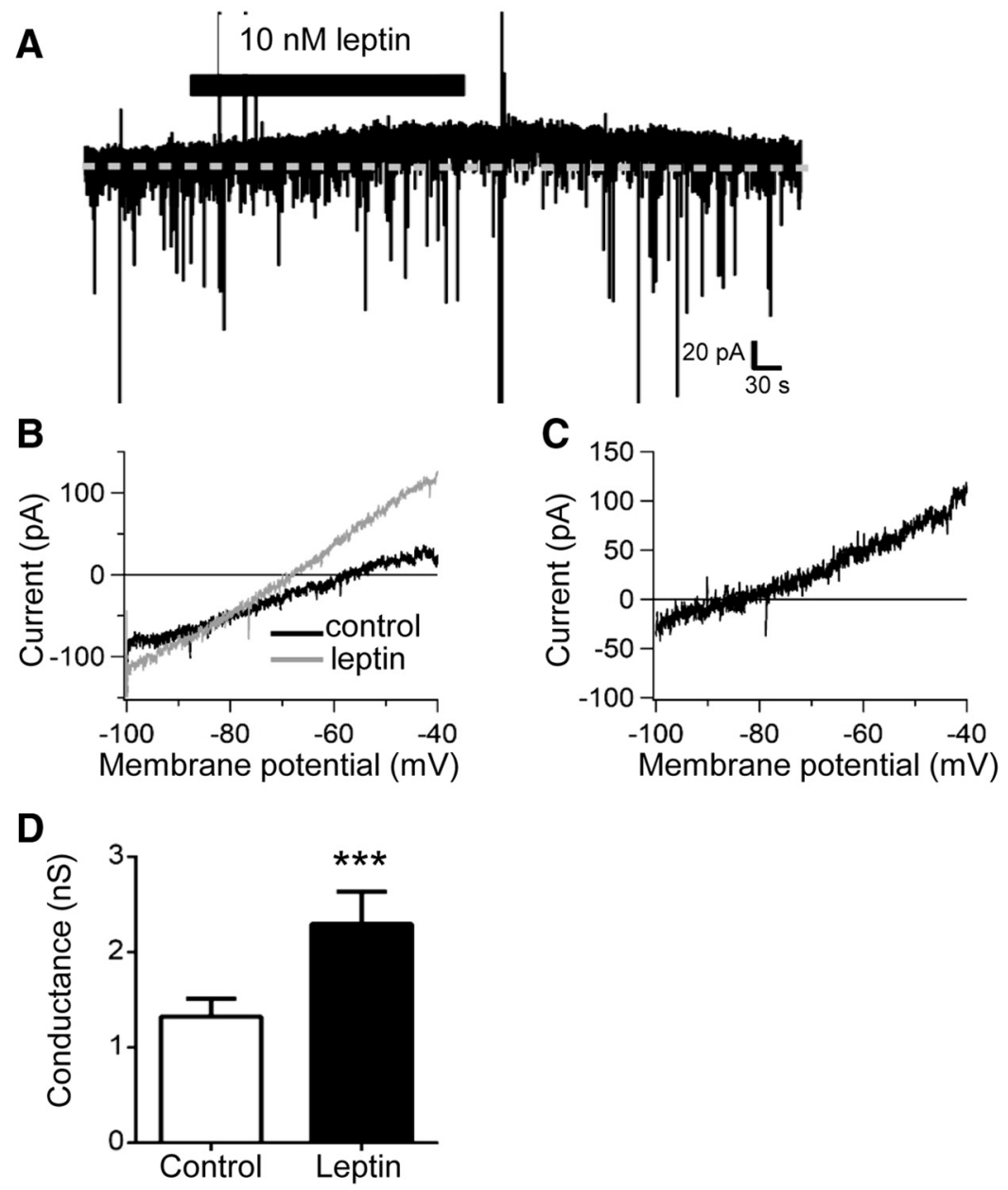

Figure 7. Leptin activates an outward current in $0 X$ neurons. $A$, Voltage-clamp recording from an individual $0 X$ neuron clamped to $-50 \mathrm{mV}$ depicting the activation of an outward current in response to acute leptin. $\boldsymbol{B}$, Representative whole-cell currents recorded from an individual $0 \mathrm{X}$ neuron in response to linear voltage ramps from -100 to $-40 \mathrm{mV}$ in the presence (gray) and absence (black) of $10 \mathrm{~nm}$ leptin. C, Representative leptin-activated whole-cell current (presence of leptin minus control) plotted against membrane potential. $\boldsymbol{D}$, Leptin significantly increased mean whole-cell conductance measured from -100 to $-50 \mathrm{mV}$ $\left(n=17,{ }^{* * *} p<0.001\right)$.

tolbutamide $(200 \mu \mathrm{M})$. A comparison of $I-V$ curves generated in the presence of leptin with or without tolbutamide show that tolbutamide blocked the leptin-activated current (Fig. 8A) and reversed the leptin-induced increase in mean whole-cell conductance (Fig. $8 B$; control, $1.4 \pm 0.3 \mathrm{nS}$; leptin, $2.3 \pm 0.6 \mathrm{nS}$; leptin/ tolbutamide, $\left.1.3 \pm 0.3 \mathrm{nS} ; p=0.01, F_{(2,12)}=6.49\right)$. In further support of leptin-induced activation of OX $\mathrm{K}_{\mathrm{ATP}}$ channels, the coapplication of leptin with tolbutamide also reversed the leptininduced hyperpolarization (Fig. 8C). Mean OX membrane potential during leptin treatment $(-53.9 \pm 1.2 \mathrm{mV})$ was significantly hyperpolarized compared with vehicle $(-47.1 \pm 2.6$ $\mathrm{mV})$ and leptin plus tolbutamide $\left(-48.5 \pm 2.2, p=0.03, F_{(2,6)}=\right.$ 6.32 ), whereas membrane potential in the presence of leptin with tolbutamide did not differ from control (Fig. 8D).

Because OX neurons are proposed to directly and indirectly excite other LHA OX neurons via glutamatergic transmission and OX peptide signaling (Li et al., 2002; Yamanaka et al., 2010), we examined whether the reduction in sEPSC frequency that we observed with leptin was caused by the opening of $\mathrm{K}_{\mathrm{ATP}}$ channels and consequent suppression of activity in neighboring $\mathrm{OX}$ neurons. Thus, we tested whether the leptin-induced inhibition of sEPSCs was blocked by the application of tolbutamide, which restored OX neuronal activity in the continued presence of leptin. However, as shown in Figure 8E, tolbutamide did not reverse the leptin-induced suppression of sEPSC frequency (normalized frequency: leptin, $68 \%$ of control; leptin plus tolbutamide, $48 \%$ of control; $p<0.0001, F_{(2,16)}=$ 38.66). This implies that the reduced activity of neighboring OX neurons attributable to leptin activation of $\mathrm{K}_{\mathrm{ATP}}$ channels does not underlie the decrease in excitatory input in response to leptin. Interestingly, sEPSC frequency decreased further in the presence of leptin plus tolbutamide versus leptin alone, suggesting that $\mathrm{K}_{\mathrm{ATP}}$ channel blockade in as yet undefined neurons may suppress excitatory input onto OX neurons.

\section{Gal receptor signaling is required for leptin action}

Our findings indicate that leptin does not regulate $\mathrm{OX}$ neurons via GABA signaling but that other neurotransmitters and/or neuropeptides are released in response to leptin and mediate OX inhibition. In addition to Nts, LepRb ${ }^{\mathrm{Nts}}$ neurons express the neuropeptide Gal (Laque et al., 2013). Thus, we examined whether acute application of Nts and/or Gal modulated OX activity in hypothalamic slices. Although we observed no significant effect of Nts (100 nm) on Ox activity overall, Nts tended to stimulate OX activity by depolarizing membrane potential in four of six OX neurons (control, $-56.9 \pm 3.1 \mathrm{mV}$; Nts, $-53.8 \pm 4.0 \mathrm{mV} ; p=0.15, t_{(5)}=$ 1.69) and increasing action potential firing in three of five OX neurons (mean normalized frequency, $156 \%$ of control; $p=0.41, t_{(4)}=0.91$, Fig. $\left.9 A, B\right)$. Conversely, Gal (100 nM) hyperpolarized membrane potential in 55\% (6 of 11) of OX neurons (Fig. 9C-E; $V_{\mathrm{m}}$ : control, $-53.7 \pm 2.3 \mathrm{mV}$; Gal, $-57.6 \pm 3.4 \mathrm{mV} ; p=0.03$, $\left.t_{(10)}=2.47\right)$ and decreased action potential firing in seven of eight OX neurons (mean normalized frequency, $44 \%$ of control; $p=$ $\left.0.003, t_{(7)}=4.46\right)$. Although these findings demonstrate an ability for Gal to inhibit OX activity, they are inconsistent with a role for Nts in the leptin-induced inhibition of OX neurons. Furthermore, coapplication of the Gal receptor antagonist M40 (Bartfai et al., 1993) prevented leptin-induced hyperpolarization of OX neurons (Figure 10; $V_{\mathrm{m}}$ : control, $-48.7 \pm 1.2 \mathrm{mV} ; \mathrm{M} 40,-48.0 \pm$ $1.1 \mathrm{mV}$; M40/leptin, $-49.2 \pm 1.1 \mathrm{mV}$; leptin only, $-53.0 \pm 0.3$ $\left.\mathrm{mV} ; p=0.0005, F_{(3,15)}=10.85\right)$, suggesting a role for $\mathrm{Gal}$ release and receptor activation in the regulation of orexin neurons by leptin.

\section{Discussion}

Fasting activates OX neurons, presumably to increase overall activity, alertness, and food-seeking behavior, thereby increasing feeding in response to negative energy balance. Decreased leptin levels mediate a crucial component of this effect, because leptin hyperpolarizes and inhibits OX neurons in hypothalamic slices and leptin replacement inhibits the activation of OX neurons 
during fasting. Although it was originally postulated that direct leptin action on OX neurons might mediate this inhibition, OX neurons do not express LepRb (Leinninger et al., 2009; Louis et al., 2010; Laque et al., 2013). However, neighboring LHA LepRb neurons lie in close contact with OX neurons, as do LHA Nts cells, many of which contain LepRb. Furthermore, deletion of LepRb from LepRb ${ }^{\mathrm{Nts}}$ cells (which are restricted to the LHA) prevents the modulation of $O x$ mRNA by leptin, as well as blocks the accumulation of c-Fos in OX neurons during fasting, suggesting a role for LepRb ${ }^{\mathrm{Nts}}$ neurons in the control of OX neurons by leptin (Leinninger et al., 2011). Indeed, our present data reveal that leptin inhibits OX neurons indirectly, by acting on LHA LepRb $^{\text {Nts }}$ cells. Furthermore, we demonstrate that two separate GABA-independent mechanisms mediate this inhibition: (1) the postsynaptic activation of an OX neuron $\mathrm{K}_{\mathrm{ATP}}$ channel; and (2) presynaptic suppression of excitatory input onto OX neurons.

The stimulation of LHA Nts neurons inhibited the activity of OX neurons, and the ability of leptin to hyperpolarize and decrease the activity of OX neurons was abrogated in Lepr $^{\text {Nts }} \mathrm{KO}$ mice. However, residual leptin responsiveness persisted in a small percentage of the OX neurons of Lepr ${ }^{N t s} \mathrm{KO}$ animals. Thus, although leptin regulation of OX neurons is predominantly mediated by LHA LepRb ${ }^{\mathrm{Nts}}$ neurons, other LHA (non-Nts) LepRb neurons may also contribute, albeit to a lesser extent.

LHA LepRb neurons contain the GABA-synthesizing enzyme GAD1, as well as vGAT (which transports GABA into synaptic vesicles for release; Leinninger et al., 2009; Vong et al., 2011), suggesting their ability to release inhibitory GABA onto their synaptic targets. Because the expression of the transsynaptic tracer wheat germ agglutinin in LHA LepRb or LHA Nts neurons accumulates in OX neurons (Louis et al., 2010; Leinninger et al., 2011), we reasoned that LHA LepRb neurons might mediate the inhibition of OX neuron activity via direct GABA release onto these cells. However, leptin failed to significantly potentiate $\mathrm{GABA}_{\mathrm{A}}$-mediated sIPSCs in OX neurons. Furthermore, the inhibition of neither $\mathrm{GABA}_{\mathrm{A}}$ nor $\mathrm{GABA}_{\mathrm{B}}$ receptors altered the ability of leptin to hyperpolarize OX neurons. Although there are inherent limitations when using a pharmacological approach to assess the involvement of specific receptor subtypes in physiological action, our data indicate that GABA action at the two main GABA receptor subtypes does not underlie leptin modulation of OX function. Rather, leptin decreased the frequency, but not amplitude, of sEPSCs in OX neurons, consistent with a presynaptic effect. $\mathrm{GABA}_{\mathrm{B}}$ receptor antagonism also failed to attenuate this leptin-promoted inhibition of sEPSCs in OX neurons. Thus, the inhibition of OX neurons by leptin is not mediated by GABA but is attributable, in part, to the GABAindependent inhibition of excitatory input to these cells. This
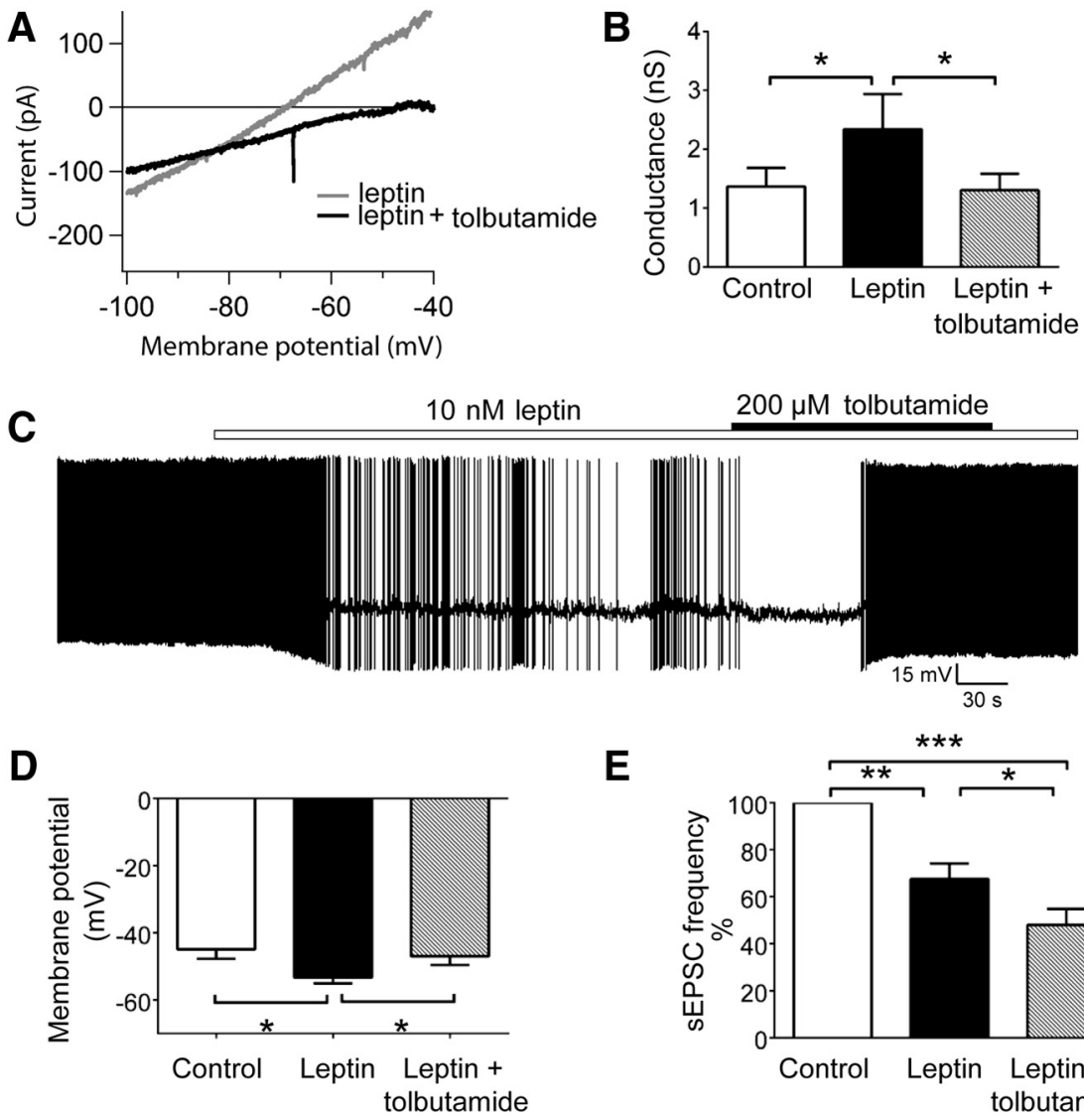

E

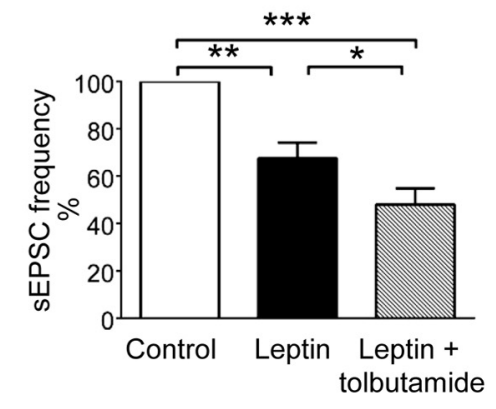

Figure 8. Leptin induces the activation of $\mathrm{K}_{\mathrm{ATP}}$ channels in $0 \mathrm{X}$ neurons. $\boldsymbol{A}$, Representative whole-cell currents recorded from an individual $0 X$ neuron in response to linear voltage ramps from -100 to $-40 \mathrm{mV}$ in the presence of $10 \mathrm{~nm}$ leptin (gray) and $10 \mathrm{~nm}$ leptin-induced decrease in sEPSC frequency. Graph depicts mean normalized sEPSC frequency $\left(n=9 ;{ }^{* *} p<0.01\right.$ for control vs leptin; ${ }^{* * *} p<0.001$ for control vs leptin plus tolbutamide; ${ }^{*} p<0.05$ for leptin vs leptin plus tolbutamide).

selective modulation of excitatory synaptic transmission is not surprising given that the majority of synaptic input that we measured in OX neurons was glutamate-dependent excitatory transmission, consistent with the predominantly excitatory synaptic architecture of OX neurons (Horvath and Gao, 2005).

A single $24 \mathrm{~h}$ fasting episode in vivo increases the frequency of mEPSCs and the number of excitatory synapses present on OX cell bodies (Horvath and Gao, 2005). These data imply that normal levels of circulating leptin exert a tonic inhibitory effect on OX neurons, partly because of the suppression of excitatory neurotransmission, and that the removal of this restraining influence not only enhances OX activity but may induce more long-lasting plasticity. In this way, leptin levels may set the dynamic range for the excitation of OX neurons and influence the integration of other physiological stimuli that modulate glutamatergic synaptic transmission in OX neurons.

In addition to the effects of leptin on excitatory inputs to OX neurons, leptin activated a $\mathrm{K}_{\mathrm{ATP}}$ channel in these neurons, which contributes to the leptin-mediated hyperpolarization of OX neurons. Leptin-induced $\mathrm{K}_{\mathrm{ATP}}$ activation is consistent with a reduced need for OX neuron activity, and therefore foraging behavior, during times of energy abundance and vice versa. OX $\mathrm{K}_{\mathrm{ATP}}$ chan- 
A

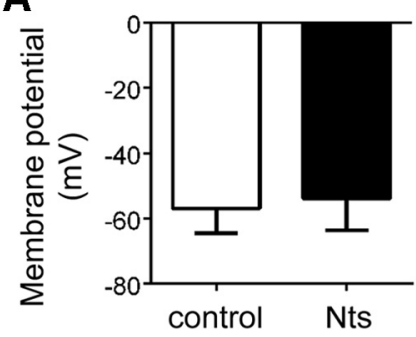

B

C
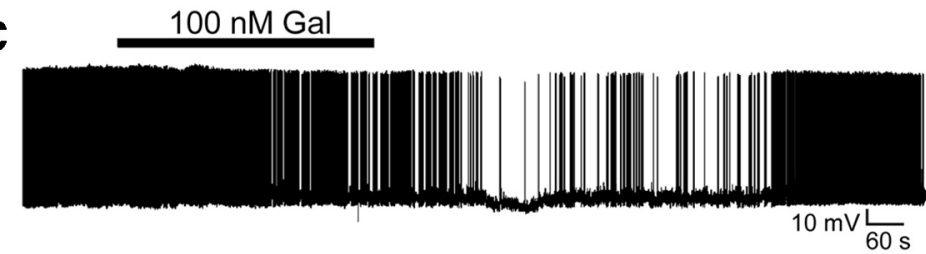

D

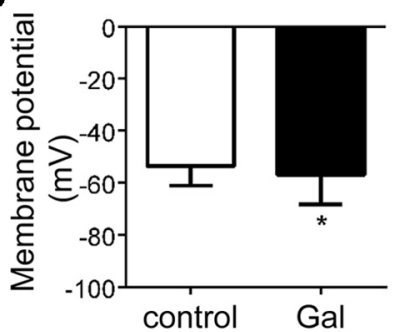

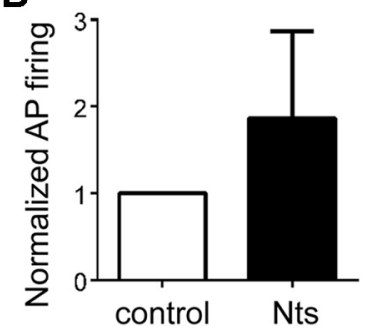

E

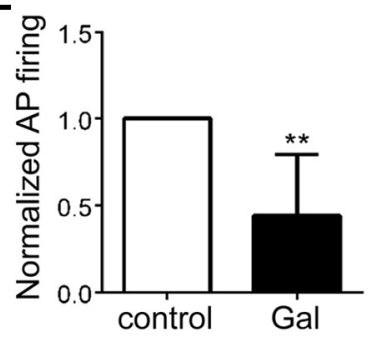

Figure 9. The effect of Nts and Gal on $0 X$ activity. Acute Nts ( $100 \mathrm{~nm})$ treatment did not significantly alter mean $0 \mathrm{X}$ neuron membrane potential $(\boldsymbol{A})$ or mean action potential firing $(\boldsymbol{B} ; n=5-6, p<0.05)$. $\boldsymbol{C}$, Current-clamp recording of membrane potential and action potential firing from an individual $0 X-E G F P$ neuron in response to $100 \mathrm{~nm}$ Gal. Gal significantly hyperpolarized the mean membrane potential $\left(\boldsymbol{D} ; n=11,{ }^{*} p<0.05\right)$ and reduced action potential firing of LHA OX neurons $\left(\boldsymbol{E} ; n=8,{ }^{* *} p<\right.$ $0.01)$.

A
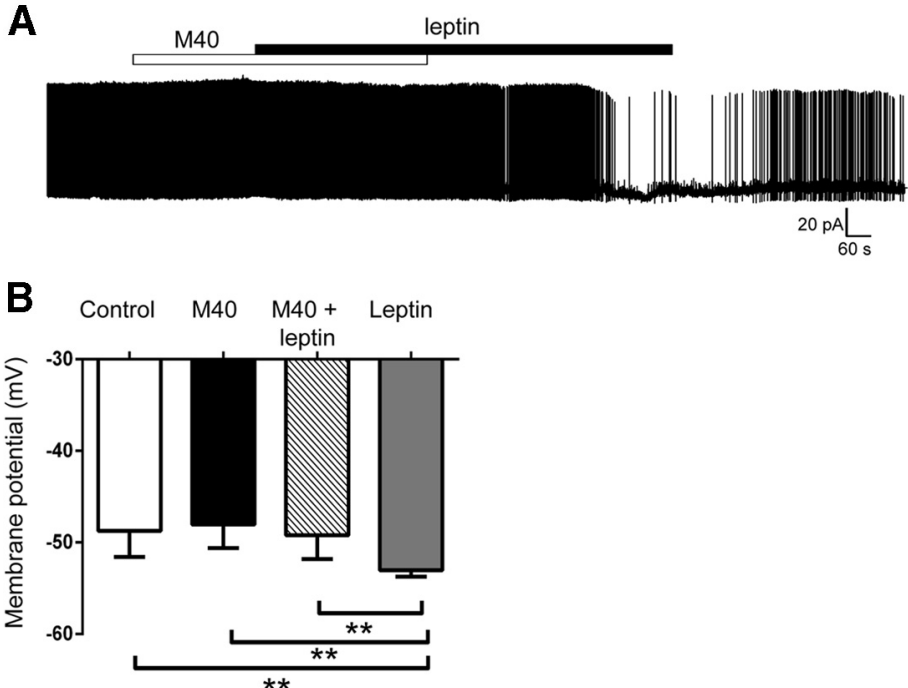

Figure 10. Gal receptor antagonism prevents leptin inhibition of $0 \mathrm{X}$ neurons. $\boldsymbol{A}$, Current-clamp recording of membrane potential from an OX neuron in response to M40 (100 $\mu \mathrm{m})$ followed by M40 plus leptin (10 nm) and leptin only. B, Coapplication of M40 plus leptin prevented the hyperpolarization of $\mathrm{OX}$ neuron membrane potential versus leptin only $\left(n=6,{ }^{* *} p<0.01\right)$.

nels, which comprise $\mathrm{K}_{\mathrm{ir}} 6.1 / \mathrm{SUR} 1$ subunits (Parsons and Hirasawa, 2010), do not directly sense glucose (González et al., 2008), but their activity is linked to multiple indicators of nutritional and energy status (Parsons and Hirasawa, 2010; Karnani et al., 2011; Liu et al., 2011). Thus, leptin modulation of OX $\mathrm{K}_{\text {ATP }}$ channels provides an additional mechanism by which OX neurons may integrate signals of energy state.
Afferents to OX neurons originate from diverse neuronal populations that reside both within and outside the LHA (Yoshida et al., 2006). Although the identities of the glutamatergic projections to OX neurons are not fully resolved, some evidence supports their regulation by local glutamatergic cells in the LHA, including other OX neurons (Li et al., 2002; Burt et al., 2011). In fact, OX peptides are autoregulatory and have been shown to stimulate OX neuron activity both directly (Yamanaka et al., 2010) and indirectly by enhancing excitatory input from LHA glutamatergic interneurons (Li et al., 2002). However, a mechanism whereby reduced sEPSC frequency occurs secondary to the silencing of neighboring and afferent OX neurons cannot explain the leptin-mediated inhibition of sEPSCs onto OX neurons, because tolbutamide, which restored OX neuron activity, failed to reverse the decrease in sEPSC frequency in response to leptin. It is possible that leptin inhibits the activity of other (non-OX) glutamatergic neurons that provide excitatory synaptic input to OX neurons. Alternatively, decreased sEPSC frequency may reflect presynaptic inhibition of glutamate release from axon terminals that are in synaptic contact with the OX neurons.

Despite the GABAergic nature of LHA LepRb neurons (Leinninger et al., 2009), leptin-mediated inhibition of OX neurons does not appear to involve the GABA system. Consistently, the disruption of GABA signaling in LepRb neurons minimally increases food intake and body weight, although animals lacking LepRb in GABA neurons are extremely hyperphagic and obese (Vong et al., 2011; $\mathrm{Xu}$ et al., 2012). Thus, although GABAergic LepRb neurons are integral to leptin action, GABA does not appear to represent the major neurotransmitter that mediates leptin action. Indeed, our results suggest that leptin regulation of OX neurons requires the involvement of other neurotransmitters and/or neuropeptides. Although LHA LepRb ${ }^{\mathrm{Nts}}$ neurons contain $\mathrm{Nts}$, as well as GABA, this peptide tended to stimulate OX activity and thus seems an unlikely mediator of leptin-mediated inhibitory signaling. In contrast, a recent publication demonstrates that some LHA LepRb neurons contain the inhibitory peptide Gal, which also colocalizes extensively with Nts in the LHA (Laque et al., 2013). Furthermore, Gal has been shown to activate $\mathrm{K}_{\mathrm{ATP}}$ channels (de Weille et al., 1988; Dunne et al., 1989; Zini et al., 1993) and inhibit synaptic glutamate release (Zini et al., 1993; Kinney et al., 1998). In this study, we further demonstrate that Gal inhibits OX activity whereas Gal receptor blockade prevents the hyperpolarization of 
OX neurons by leptin, suggesting that Gal secretion from $\mathrm{LepRb}^{\mathrm{Nts}}$ neurons and subsequent Gal receptor activation contributes to leptin regulation of OX function. Here, we demonstrate the ability for LHA LepRb neurons to inhibit OX neurons in the LHA. Our results are consistent with a model whereby leptin exerts a tonic inhibitory effect on OX neurons, and their disinhibition by decreasing leptin levels stimulates OX neuron activity to trigger arousal, locomotor activity, and feeding during periods of acute starvation. Although our studies address the response of OX neurons to acute changes in leptin levels, it will be important for future studies to examine how OX neurons integrate signals, including leptin, over the long term to maintain energy homeostasis.

\section{References}

Acuna-Goycolea C, van den Pol A (2004) Glucagon-like peptide 1 excites hypocretin/orexin neurons by direct and indirect mechanisms: implications for viscera-mediated arousal. J Neurosci 24:8141-8152. CrossRef Medline

Acuna-Goycolea C, Li Y, Van Den Pol AN (2004) Group III metabotropic glutamate receptors maintain tonic inhibition of excitatory synaptic input to hypocretin/orexin neurons. J Neurosci 24:3013-3022. CrossRef Medline

Alexander GM, Rogan SC, Abbas AI, Armbruster BN, Pei Y, Allen JA, Nonneman RJ, Hartmann J, Moy SS, Nicolelis MA, McNamara JO, Roth BL (2009) Remote control of neuronal activity in transgenic mice expressing evolved G protein-coupled receptors. Neuron 63:27-39. CrossRef Medline

Armbruster BN, Li X, Pausch MH, Herlitze S, Roth BL (2007) Evolving the lock to fit the key to create a family of $\mathrm{G}$ protein-coupled receptors potently activated by an inert ligand. Proc Natl Acad Sci U S A 104:51635168. CrossRef Medline

Bartfai T, Langel U, Bedecs K, Andell S, Land T, Gregersen S, Ahrén B, Girotti P, Consolo S, Corwin R, Crawleys J, Xu X, Wiesenfeld-Hallin Z, Hokfelt T II (1993) Galanin-receptor ligand M40 peptide distinguishes between putative galanin-receptor subtypes. Proc Natl Acad Sci U S A 90:1128711291. CrossRef Medline

Burt J, Alberto CO, Parsons MP, Hirasawa M (2011) Local network regulation of orexin neurons in the lateral hypothalamus. Am J Physiol Regul Integr Comp Physiol 301:R572-R580. CrossRef Medline

de Weille J, Schmid-Antomarchi H, Fosset M, Lazdunski M (1988) ATPsensitive $\mathrm{K}+$ channels that are blocked by hypoglycemia-inducing sulfonylureas in insulin-secreting cells are activated by galanin, a hyperglycemia-inducing hormone. Proc Natl Acad Sci U S A 85:13121316. CrossRef Medline

Diano S, Horvath B, Urbanski HF, Sotonyi P, Horvath TL (2003) Fasting activates the nonhuman primate hypocretin (orexin) system and its postsynaptic targets. Endocrinology 144:3774-3778. CrossRef Medline

Dunne MJ, Bullett MJ, Li GD, Wollheim CB, Petersen OH (1989) Galanin activates nucleotide-dependent $\mathrm{K}+$ channels in insulin-secreting cells via a pertussis toxin-sensitive G-protein. EMBO J 8:413-420. Medline

Fu LY, Acuna-Goycolea C, van den Pol AN (2004) Neuropeptide Y inhibits hypocretin/orexin neurons by multiple presynaptic and postsynaptic mechanisms: tonic depression of the hypothalamic arousal system. J Neurosci 24:8741-8751. CrossRef Medline

González JA, Jensen LT, Fugger L, Burdakov D (2008) Metabolismindependent sugar sensing in central orexin neurons. Diabetes 57:25692576. CrossRef Medline

Hamill OP, Marty A, Neher E, Sakmann B, Sigworth FJ (1981) Improved patch-clamp techniques for high-resolution current recording from cells and cell-free membrane patches. Pflugers Arch 391:85-100. CrossRef Medline

Horvath TL, Gao XB (2005) Input organization and plasticity of hypocretin neurons: possible clues to obesity's association with insomnia. Cell Metab 1:279-286. CrossRef Medline

Jones DN, Gartlon J, Parker F, Taylor SG, Routledge C, Hemmati P, Munton RP, Ashmeade TE, Hatcher JP, Johns A, Porter RA, Hagan JJ, Hunter AJ, Upton N (2001) Effects of centrally administered orexin-B and orexin-A: a role for orexin-1 receptors in orexin-B-induced hyperactivity. Psychopharmacology (Berl) 153:210-218. CrossRef Medline
Karnani MM, Apergis-Schoute J, Adamantidis A, Jensen LT, de Lecea L, Fugger L, Burdakov D (2011) Activation of central orexin/hypocretin neurons by dietary amino acids. Neuron 72:616-629. CrossRef Medline

Kinney GA, Emmerson PJ, Miller RJ (1998) Galanin receptor-mediated inhibition of glutamate release in the arcuate nucleus of the hypothalamus. J Neurosci 18:3489-3500. Medline

Krashes MJ, Koda S, Ye C, Rogan SC, Adams AC, Cusher DS, Maratos-Flier E, Roth BL, Lowell BB (2011) Rapid, reversible activation of AgRP neurons drives feeding behavior in mice. J Clin Invest 121:1424-1428. CrossRef Medline

Laque A, Zhang Y, Gettys S, Nguyen TA, Bui K, Morrison CD, Münzberg H (2013) Leptin receptor neurons in the mouse hypothalamus are colocalized with the neuropeptide galanin and mediate anorexigenic leptin action. Am J Physiol Endocrinol Metab 304:E999-E1011. CrossRef Medline

Leinninger GM, Jo YH, Leshan RL, Louis GW, Yang H, Barrera JG, Wilson H, Opland DM, Faouzi MA, Gong Y, Jones JC, Rhodes CJ, Chua S Jr, Diano S, Horvath TL, Seeley RJ, Becker JB, Münzberg H, Myers MG Jr (2009) Leptin acts via leptin receptor-expressing lateral hypothalamic neurons to modulate the mesolimbic dopamine system and suppress feeding. Cell Metab 10:89-98. CrossRef Medline

Leinninger GM, Opland DM, Jo YH, Faouzi M, Christensen L, Cappellucci LA, Rhodes CJ, Gnegy ME, Becker JB, Pothos EN, Seasholtz AF, Thompson RC, Myers MG Jr (2011) Leptin action via neurotensin neurons controls orexin, the mesolimbic dopamine system and energy balance. Cell Metab 14:313-323. CrossRef Medline

Li Y, Gao XB, Sakurai T, van den Pol AN (2002) Hypocretin/orexin excites hypocretin neurons via a local glutamate neuron-A potential mechanism for orchestrating the hypothalamic arousal system. Neuron 36:11691181. CrossRef Medline

Liu ZW, Gao XB (2007) Adenosine inhibits activity of hypocretin/orexin neurons by the $\mathrm{A} 1$ receptor in the lateral hypothalamus: a possible sleeppromoting effect. J Neurophysiol 97:837-848. CrossRef Medline

Liu ZW, Gan G, Suyama S, Gao XB (2011) Intracellular energy status regulates activity in hypocretin/orexin neurones: a link between energy and behavioural states. J Physiol 589:4157-4166. CrossRef Medline

Louis GW, Leinninger GM, Rhodes CJ, Myers MG Jr (2010) Direct innervation and modulation of orexin neurons by lateral hypothalamic LepRb neurons. J Neurosci 30:11278-11287.

Lubkin M, Stricker-Krongrad A (1998) Independent feeding and metabolic actions of orexins in mice. Biochem Biophys Res Commun 253:241-245. CrossRef Medline

Matsuki T, Nomiyama M, Takahira H, Hirashima N, Kunita S, Takahashi S, Yagami K, Kilduff TS, Bettler B, Yanagisawa M, Sakurai T (2009) Selective loss of $\mathrm{GABA}(\mathrm{B})$ receptors in orexin-producing neurons results in disrupted sleep/wakefulness architecture. Proc Natl Acad Sci U S A 106: 4459-4464. CrossRef Medline

Morrison SD, Barrnett RJ, Mayer J (1958) Localization of lesions in the lateral hypothalamus of rats with induced adipsia and aphagia. Am J Physiol 193:230-234. Medline

Parsons MP, Hirasawa M (2010) ATP-sensitive potassium channelmediated lactate effect on orexin neurons: implications for brain energetics during arousal. J Neurosci 30:8061-8070. CrossRef Medline

Parsons MP, Belanger-Willoughby N, Linehan V, Hirasawa M (2012a) ATP-sensitive potassium channels mediate the thermosensory response of orexin neurons. J Physiol 590:4707-4715. CrossRef Medline

Parsons MP, Burt J, Cranford A, Alberto C, Zipperlen K, Hirasawa M (2012b) Nociceptin induces hypophagia in the perifornical and lateral hypothalamic area. PLoS One 7:e45350. CrossRef Medline

Paxinos G, Franklin B (2001) The mouse brain in stereotaxic coordinates, Ed 2. San Diego: Academic.

Perez-Leighton CE, Boland K, Teske JA, Billington C, Kotz CM (2012) Behavioral responses to orexin, orexin receptor gene expression, and spontaneous physical activity contribute to individual sensitivity to obesity. Am J Physiol Endocrinol Metab 303:E865-E874. CrossRef Medline

Rao Y, Liu ZW, Borok E, Rabenstein RL, Shanabrough M, Lu M, Picciotto MR, Horvath TL, Gao XB (2007) Prolonged wakefulness induces experience-dependent synaptic plasticity in mouse hypocretin/orexin neurons. J Clin Invest 117:4022-4033. CrossRef Medline

Rao Y, Mineur YS, Gan G, Wang AH, Liu ZW, Wu X, Suyama S, de Lecea L, Horvath TL, Picciotto MR, Gao XB (2013) Repeated in vivo exposure of cocaine induces long-lasting synaptic plasticity in hypocretin/orexin neu- 
rons in the lateral hypothalamus in mice. J Physiol 591:1951-1966. CrossRef Medline

Sakurai T, Amemiya A, Ishii M, Matsuzaki I, Chemelli RM, Tanaka H, Williams SC, Richarson JA, Kozlowski GP, Wilson S, Arch JR, Buckingham RE, Haynes AC, Carr SA, Annan RS, McNulty DE, Liu WS, Terrett JA, Elshourbagy NA, Bergsma DJ, Yanagisawa M (1998) Orexins and orexin receptors: a family of hypothalamic neuropeptides and G proteincoupled receptors that regulate feeding behavior. Cell 92:1 page following 696. CrossRef Medline

Sakurai T, Moriguchi T, Furuya K, Kajiwara N, Nakamura T, Yanagisawa M, Goto K (1999) Structure and function of human prepro-orexin gene. J Biol Chem 274:17771-17776. CrossRef Medline

Sweet DC, Levine AS, Billington CJ, Kotz CM (1999) Feeding response to central orexins. Brain Res 821:535-538. CrossRef Medline

Toshinai K, Date Y, Murakami N, Shimada M, Mondal MS, Shimbara T, Guan JL, Wang QP, Funahashi H, Sakurai T, Shioda S, Matsukura S, Kangawa K, Nakazato M (2003) Ghrelin-induced food intake is mediated via the orexin pathway. Endocrinology 144:1506-1512. CrossRef Medline

Tsujino N, Sakurai T (2009) Orexin/hypocretin: a neuropeptide at the interface of sleep, energy homeostasis, and reward system. Pharmacol Rev 61:162-176. CrossRef Medline

Vong L, Ye C, Yang Z, Choi B, Chua S Jr, Lowell BB (2011) Leptin action on
GABAergic neurons prevents obesity and reduces inhibitory tone to POMC neurons. Neuron 71:142-154. CrossRef Medline

Xie X, Crowder TL, Yamanaka A, Morairty SR, Lewinter RD, Sakurai T, Kilduff TS (2006) GABA(B) receptor-mediated modulation of hypocretin/orexin neurones in mouse hypothalamus. J Physiol 574:399-414. CrossRef Medline

Xu Y, O’Brien WG 3rd, Lee CC, Myers MG Jr, Tong Q (2012) Role of GABA release from leptin receptor-expressing neurons in body weight regulation. Endocrinology 153:2223-2233. CrossRef Medline

Yamanaka A, Beuckmann CT, Willie JT, Hara J, Tsujino N, Mieda M, Tominaga M, Yagami Ki, Sugiyama F, Goto K, Yanagisawa M, Sakurai T (2003) Hypothalamic orexin neurons regulate arousal according to energy balance in mice. Neuron 38:701-713. CrossRef Medline

Yamanaka A, Tabuchi S, Tsunematsu T, Fukazawa Y, Tominaga M (2010) Orexin directly excites orexin neurons through orexin 2 receptor. J Neurosci 30:12642-12652. CrossRef Medline

Yoshida K, McCormack S, España RA, Crocker A, Scammell TE (2006) Afferents to the orexin neurons of the rat brain. J Comp Neurol 494:845861. CrossRef Medline

Zini S, Roisin MP, Langel U, Bartfai T, Ben-Ari Y (1993) Galanin reduces release of endogenous excitatory amino acids in the rat hippocampus. Eur J Pharmacol 245:1-7. CrossRef Medline 